immediately manifest in polarisation effects, the plates becoming more uniformly and rapidly peroxidised when used as positive electrodes, and local action entirely disappearing. These mercury amalgamated plates at once give me an advance of other cells. I used them in many ways, constructing cells in which the positive plate was amalgamated, and the negative coated with red oxide, or with peroxide, produced by treating red oxide with dilute hydric nitrate till the brown precipitate of peroxide fell, the precipitate being washed and painted on the electrode. I also amalgamated the negative electrode simply. I found that in every way positive electrodes amalgamated produced the best results. I also made cells in which either peroxide or red oxide was formed into a porous conglomerate, using the conglomerates as electrodes, immersed in dilute hydric'sulphate. I constructed cells with parallel plates, red oxide or peroxide being filled in between the plates; in this experiment red oxide is useless and peroxide efficient. In all these experiments I succeeded in storing electricity to different extents.

Having thoroughly satisfied myself that positive electrodes amalgamated with mercury were the best, I investigated the behaviour of various forms of negative electrode, having in view the conservation of the hydrogen; this I thought to do by occluding the hydrogen in suitable electrodes, as spongy platinum or metallic palladium; but as both these methods would be useless owing to expense I did not even experiment on them.

I further thought of having negative electrodes, whose oxides should be soluble in the solution, and which could be redeposited from the solution, or of having metallic solutions from which metal could be deposited, the resulting solution being such that should, on the oxidation of the deposited metal, combine with the oxide and again form the original solution.

I thought that success in this manner would result in a powerful and constant source of stored energy, the cell would not polarise itself during discharge, as is the case in both Planté and Faure cells; in these cells the peroxide formed by the discbarge produces a contrary electromotive force.

Experimenting from this train of thought, the results I have obtained are such as to have an important practical bearing on the future of electric work.

The experiments comprised amalgamated lead as a positive electrode with negative electrodes composed of either zinc, iron, or copper, in each case the solution between the electrodes being a salt of the metal composing the negative electrode. With zinc, sulphate of zinc was the solution; with iron, sulphate of iron; and with copper, sulphate of copper. In all these cases the results were not only far more powerful than with any form of cell I had previously devised, but also very constant, the polarisation lasting many times longer than in any other form of cell. The cell with zinc negative electrode I discarded, owing to the necessity there would be to keep the zinc plate amalgamated to prevent local action; the iron negative electrode was set aside owing to the iron oxidising when the cell was not in use. The cell having a negative electrode of copper, a positive electrode of lead amalgamated with mercury and a solution of cupric sulphate, I have adopted as a thoroughly economical, lasting, and practical form of storage reservoir. The chemical changes in this cell are exceedingly interesting and beautiful, the cell being composed of a sheet of lead cleaned with dilute sulphuric acid and amalgamated thoroughly with mercury, and a sheet of thin copper a little shorter; the two sheets are perforated with a number of holes and then rolled in a spiral, separated by rubber bands cut every five inches, the holes in plates and cuts in rubber bands being to allow free circulation of the solution (the short plate being uppermost before rolling). This combination is immersed in a solution of cupric sulphate, and the amalgamated lead plate made the positive electrode of a suitable source of electricity, the chemical action being that the oxygen of the decomposed solution combines with the lead, forming a perfectly even coating of the insoluble peroxide, the hydrogen replacing the copper of the solution, and the copper being deposited in the metallic state on the negative electrode. As the decomposition of the cupric sulphate proceeds the solution gradually loses its azure blue colour, becoming more acid, and finally when the whole of the copper is deposited, we have the solution colourless and transformed into hydric sulphate and water, the positive electrode peroxidised and copper deposited on the negative electrode. During discharge the peroxide is reduced and the copper element oxidised, the oxide combining with the acid and forming cupric sulphate, the solution re turning to its original colour. This change of colour forms a beautiful means of telling when the cell is charged; it is a veritable charging gauge. The power of this cell is very great and very constant; it can be made to last for hours, the time being dependent on the quantity of cupric sulphate decomposed.

I have, by the decomposition and recomposition of one pint of cupric sulphate, obtained over two hours' effective work in heating to a red heat one inch of No. 28 iron wire, the cell measuring internally 4 inches deep and 4 inches diameter.

I constructed cells with free crystals of cupric sulphate suspended in the solution, and found that the presence of free crystals prevented the oxidation of the amalgamated lead electrode, it being essential that the solution become slightly acid before the peroxide will form. The cell during charging gives out a peculiar rattling noise, which I consider due to the deposition of copper on the negative electrode altering the form of the spiral.

A practical form of cell for storing purposes ought to be made, by fixing a series of amalgamated lead plates in a box in grooves, as in Cruikshank's trough battery, filling the interval between the plates with solution of cupric sulphate, and passing a current through of sufficient tension to overcome the contrary electromotive force of the series, the positive sides of the plates being peroxidised and copper deposited on the negative sides. I have two boxes on this plan, each containing twentyfive plates, the total being equivalent to fifty cells. By this means batteries of great tension can be charged from thirty Bunsens. A number of twenty-five plate boxes can be coup'ed for quantity of charging, and for tension during discharge. Twenty such boxes, one foot square, internal measurement, will give in series a battery of 500 pairs of one foot square plates.

It will be seen from the foregoing that this method of conserving energy has a wide field before it, and as it will benefit fellow-workers in science, placing in their hands a means of experimenting with powerful electric currents, I give it without reservation, freely and untrammelled by patent rights, for their use.

\section{THE BISCHOFFSHEIM OBSERVATORY}

THIS observatory built at the expense of M. R. Bischoffsheim, the member of the French Lower House for Nice, is situated on Mont Gros, at an altitude of about 370 metres, and at a distance of eight English miles on the old Route de la Corniche, so well known and appreciated by the tourists travelling by road from Nice to Genoa. M. Celora, Milan astronomer, Commander Bahat of the French Staff, and M. Perrotin, the present director of theBischoffsheim Observatory, have ascertained electrically and astronomically, the longitude and latitude of the new establishment which has been connected with Paris and Milan, by unquestionable observations.

The buildings have been constructed under the direct supervision of M. Garnier, the architect of the Paris 
Opera, and distributed skilfully in several favourable sites of a large park having a surface of 80 acres.

The smaller meridian circle by Gauthier is in its p!ace, and can be used for daily determinations. The large meridian circle by Brüner will be finished in the first month of 1882. The object glass has 8 inches diameter, and has been focussed to a distance of ro feet. The smaller equatorial with an object-glass of 14 inches, and focussed to 27 feet, has been made by Eichens, and will be ready for observations at the same time as the larger meridian circle. The laryer equatorial will have an object-glass of 28 inches, and will be focussed to 52 feet. The glasses have been made by Feil; Henry Brothers are polishing them. The instrument will be constructed by Eichens and Gauthier. The work is proceeding favourably, but it is impossible to state when it will be completed.

M. Lœwy, sub-director of the Paris Observatory, has designed an apparatus for preventing the perturbations produced by the flexion of the axis when observations are taken at a large angular distance from the zenith. The building will have a diameter of sixty-four feet, with a rotating roof of copper, worked by hand-machinery, as designed by Gardiner.

The Bischoffsheim observatory will not be confined to astronomical observations. The donor having been taught by Leverrier in astronomy has felt it a duty to extend his donation to magnetical and meteorological observations, too often neglected in French observatories. A magnetical pavilion has been built with extensive cellars, for continuous self-registering apparatus. The registration takes place by photography as in Kew, and is made with instruments by Adie, the maker of the Kew set of registers. As in Kew, a "rez-de-chaussée" has been built for direct force and direction observations. The instruments have been made by Brunner.

The installation of the meteorological instruments has been made under the direct supervision of M. Mascart, the director of the French Meteorological Cffice. A constant staff has been selected by M. Bischoffsheim, and is now on duty. The direction has been given to M. Perrotin, formerly assistant astronomer to M. Tisserand when he was director of Toulouse Observatory. The assistant astronomer is M. Carvallo, formerly a pupil in the Polytechnic School, and who has taken his astronomical honours in the special school established by Rear-Admiral Mouchez at the Paris Observatory. M. Puiseux, formerly pupil of the Polytechnic School, will have the control of magnetical and meteorological observations.

Two houses have been built-one for the administration and the other for the direction. The first floor of this staircase has been fitted up entirely for boarding foreign astronomers who are desirous of making observations in this magnificent astronomical "caravanseraï," M. and MIdme. Struve and M. Tachini have promised already to spend some time there next winter.

It should be noted that it was probably in a tour made in England with Leverrier, when the great astronomer was made an honorary doctor of Cambridge University, that M. Bischoffsheim meditated on the opportunity of establishing an observatory entirely of his own. Up to that time he had spent his time in the observation of stars which shine in a less elevated sphere than the heavenly skies. But Leverrier's conversation and intimacy led him to appreciate other unfading beauties.

The Bureau des Longitudes has agreed to take possession of the observatory, which will be handed over to it with a sufficient endowment to keep it decently. It is estimated that the money spent in purchasing the estate, \&c., will exceed $120,000 l$, and that the endowment will be more than 2000 l. a year. This handsome donation must be noted as being a revolution in French generosity towards science. Up to this time our neighbours confined themselves to bequeathing legacies and lavishing posthumous generosities.

\section{FOSSIL FLORA OF SUMATRA ${ }^{2}$}

THIS is a paper of some twenty pages and six plates. Herr Verbeek sent in 1874 a small collection of fossil plants from Sumatra to Switzerland, which were described by Heer, and in the following year the second collection, now described, was received, no others having been found in the interval. The plates contain twentytwo figures, most of them representing fragments of simple ovate leaves, supposed, with two exceptions, to be allied to existing species of the Indian mainland or archipelago. The mollusca in the overlying strata point to an Eocene age. The exceptions are a Eucalyptus and a small leafiet ascribed to Cassia, and now represented, it is here supposed, by $C$. lavigate of tropical America, but the determination rests on slender grounds. The majority of them, in fact, though doubtless the best that could be made from such material, must necessarily be almost mere guesses. The value of such guesses may be inferred from a similar work by the same author on the fossil flora of Madeira.

In this case several of the commonest indigenous plants of Madeira were referred to extra-Madeiran plants. For instance, the terminal leaflets of Rubus discolor were referred to Corylus australis, and various leaflets of Rubus grandiflora are figured as Corylus australis, Ulmus suberosa, and Psoraleadentata; the so-called Pistacea Phaacum is the common myrtle, the Ilex Hartingi is the Madeira Vaccinium, and the figures of Myrica Faya belong to Ardisia excelsa. In this case the mistakes are the more singular, as Prof. Heer had actually sojourned in Madeira, and the plants are the commonest on the island. If with even exceptionally favourable circumstances such mistakes can be made, generalisers should surely be cautious in building theories upon the ages of formations, \&c., when they have been determined upon the evidence of fossil plants. It is unfortunate that on evidence as trivial, and even more questionable, we read in Lyell of the M.IOCENE outbursts of Mull, of Iceland, and Greenland, of the Mrocene deposits of Bovey Tracy, \&c.

It is important, however, that fossil plants should be figured and described, for if the generic and specific names, except when based on ample material, are regarded merely as an individual opinion, the determinations become of use. Whatever is unsatisfactory in the work is inherent to the subject, for few possess the zeal and untiring industry of Heer. If he would only make clear to his readers the reasons which enable him in his own mind to determine the genus to which an ordinary type of leaf, with neither top nor base, belongs, and would be less positive where nothing positive is possible, his works would acquire a scientific value which some justly think they hardly at present possess.

J. S. G.

$$
\text { THE VOYAGE OF THE "VEGA" } 2
$$

II.

BARON NORDENSKJÖLD frequently refers to what Mr. Leslie renders "self-dead" animals, meaning animals that have died a natural death, in distinction to those that have been killed by hunters or by other animals. The rarity of such "self-dead" animals is remarkable, especially along the north coast of Asia, where there are few hunters and fishers, and where immense numbers of animals must die. While sailing along the Taimur coast, large numbers of dead fish (Gadus polaris) were seen lying on a block of ice, and strewed along the bottom of the sea, which Baron Nordenskiöld notices as being very unusual.

${ }^{1}$ By Dr. Oswald Heer (Neue Denkschriften der schweizerischen Gesellschaft, vol, xxviii. Zürich, r881).

Review Voyage of the Vega round Asia and Europe; with a Historical Review of previous Journeys along the North Coast of the Old World." By A. E. Nordenskjöld. Translated by Alexander Leslie. Five stee and Co., r881.) Continued from p. 183. 